\title{
VIENTO EN EL SAUCE
}

\author{
Juanita Soledad Holgado Quehuarucho*
}

Los recuerdos vienen como garua de invierno, caen lentamente sobre nuestro techo rojo, que aún conservan los guardianes pucará que colocaron tus manos fuertes. Es en nuestra casa antigua y en nuestro patio viejo, donde recorre tu imagen como luz al iniciar el día, entonces vuelvo a ver que en mis primeros alientos, y mis primeros pasos diste fuerza y ternura a lo que fue, la infancia mía.

Ésta es la historia de muchos, de los que aún guardan en sus miradas, aquella pena negra que duele en el alma, tristeza que revienta como granizo sobre el campo verde, sobre la puna, sobre roca, y emerge como melodía en quena, lanzada al viento.

Esta mañana fría, quiero recordarte, como mi árbol viejo, porque en tus ramas aún posan aventuras y sueños, enseñanzas de bien y valores, que aún me siguen como luna en esta travesía. La historia de tu madre, de la hermosa flor que rebelde de amor, retando al destino que para ella vestía, fue presa de injusticia, marchita del embrujo del deshonor.

En tu Tumibamba, en tu pampa de Anta, en tu casa lejana, aún respira aquella mujer que en sus brazos te adoraba, tiembla aún el recuerdo de aquella insensata, que en cuna de oro naciera, que siendo mujer fue la más preciada perla, niña de hacienda, vestido blanco, promesas eternas.

El dinero que brindó poder a los mezquinos, dueños de todo, aquellos que humillaban, a una supuesta raza inferior, indios los llamaban; de aquel abuso, de aquel insulto quedan memorias, que muchos guardan. No quisiera envenenarme el alma, sin embargo, sigue amargo aquel bocado de nada.

Niña hermosa, piel clara, ojitos brillantes, María bautizada, la segunda hija, la primera dama, luz en los ojos de Don Santos, muñeca de porcelana. Crecía en la hacienda, corría y jugaba, aprendió de su madre costura y galopada. No sufría las penurias que detrás del enorme cerco asomaban, de las chozas, de las miradas claras y profundas que por ahí rondaban.

Los años pasaron muy pronto, y como flor en primavera, María creció, se sumergió en el río eterno de la ternura y aún con sus ojos de niña, con esa dulce mirada, llenaba los pasillos de la inmensa casa con esa luz que sólo de ella emanaba.

Don Santos, dueño de la hacienda Timpu, orgulloso de la belleza e inteligencia de su hija que se rehusaba a quedarse en casa para aprender de su madre, el bordado o el tejido, y demás quehaceres que para esa época, "toda mujer debía de saber".

Con voz firme y decidida decía mientras acariciaba el cabello cano de su padre - yo no puedo esperar de la vida, encontrarme sin batallas ganadas, yo quiero estudiar, ser maestra y viajar, por favor papá-. El sueño de la joven, se había vuelto realidad y su padre, accediendo, también soñaba verla llegar con sus 
libros, escuchar las interminables historias, verla contagiar de ese entusiasmo a cada persona, en las escuelas, en las alturas, y llanos, en su Anta sin par. Habitaba en sus pensamientos la imagen clara de su hija, la maestra, dejando rastro.

Era, definitivamente una mujer desafiante, con un futuro por venir, pero, como en toda historia el destino se impuso, y sin caprichos pulió lentamente el camino que ella debía seguir. Faltaban muy pocos días para el esperado viaje, María se iría a la ciudad, todos en casa sentían ya su ausencia, la casa sin su niña quedaría como la pampa al atardecer, con la melancolía del día, con el susurro de la noche.

Llegó un nuevo día, la muchacha se destinaba a galopar, "El esperanza", guía en tinieblas, como fiero guardián, la llevaría como en alas, ella sintiendo en los brazos su libertad; duro fue el camino, y más lento el paso, el caballo se detuvo y bebió del cristal del río.

María, entonces, pudo ver por primera vez, la frontera de sus tierras, logró ver a su hermano, ordenando y gritando con un largo látigo, vio las humildes miradas de los pobres peones, el miedo en sus rostros, mujeres cosechando el maíz amarillo, sus wawas en las espaldas llorando de hambre bajo el incesante sol, vio el terror que imponía Juan de Matta, su propia sangre.

Desconcertada y callada, con el viento en el rostro, avanzó lentamente hacía su albo compañero, lo abrazó, como se abraza con el corazón, como cuando la garganta aprieta y todos sus pensamientos, desbordaron en llanto. Se dirigía a su casa, en una pausada caminata; no quería llegar, no quería ver los ojos de su padre, no quería ver a su madre tejiendo y tejiendo con tanta paz, como si el mundo fuera aquella casa grande, llena de comodidades, de sonrisas, de tranquilidad. María desvió el camino, quería regresar, poner un alto a todo lo que ocurría, solo quería perderse en el enorme maizal. En ese momento, una voz fuerte, preguntó - ¿qué hace usted ahí?-, ella dándose vuelta, vio un hombre moreno de ojos verdes y claros, entonces respondió la muchacha - mi nombre el María, hija del hacendado de éstas tierras-, con cierta duda preguntó - ¿quién es usted?-, -soy Víctor, capataz de Don Julio, dueño de las tierras vecinas-, respondió. El viento corría y del maizal se desprendía un sonido profundo de soledad, hubo silencio, demasiado silencio, solo miradas y palabras sin voz, era la primera vez que María se enamoraba.

En el camino largo contaron su historia, Víctor era de hijo de comerciantes, que cargados de familia, hacían patria de pueblo en pueblo, ya con la vejez, terminaron en Tumibamba, es como el muchacho se empleó en la hacienda Sumaq Tika, para ser capataz y domador de caballos, llevaba la afición de los gallos, y en la fiesta del pueblo con el ajiseco bajo el poncho retaba a los hijos de hacendados, tenía victorias y desventuras, y en aquellos ojos verdes, se veía también el dolor por sus hermanos campesinos, decía - yo he visto a Juan de Matta, golpear, insultar y escupir a mis hermanos, todos somos hermanos, nos une el dolor-, María con voz quebrada dijo - lo he visto y se me estrujó el corazón-, sin decir nada más, llegaron al río, era el fin del camino, pero no el fin del suyo.

Pasaron los días, como tranvías en la ciudad; María y Víctor se veían cada vez que se daba una oportunidad, estaba cercano el día del viaje de la muchacha, él había vendido dos de sus vacas, quería llevarla y visitarla mientras ella estudiaba, sin embargo el joven romance llegó a oídos de Don Santos, quién no dudó un segundo en demostrar su enojo; con voz ronca y grave como estruendo de relámpago que en enero agita la bella llanura, entre gritos y amenazas dio su última sentencia -si del amor de ese 
pobre infeliz capataz se trata, pues ya no eres más mi hija, jamás olvidaré esta humillación, desde hoy reniego de ti, y te marcharás dejando todo lo que te ofrecí-, la jovencita indignada en brazos de su madre, sujetó en sus manos sus ganas de llorar y con voz valiente dijo - no seré parte de este mundo ni de tu abuso-,el padre, tratando de hacerla entrar en razón, dijo algo de lo que jamás María se recuperaría, contrario a tu decisión, tienes que saber qué es lo que te conviene, puedo darte en matrimonio con el hijo de mi compadre, dueño de la finca de Sullupuqio, o con uno de la hacienda de Tankarniyoq, el silencio se apodera de todo, esa noche oscura inmensa, eterna con el aroma del manzano, se perdía entre el aullido lejano y solitario del guardacasacha hasta la madrugada.

Se asoma el sol, y la estrella se perdió, la noche no la contuvo. Está el desayuno en la mesa, la leche fresca recién ordeñada, el pan de trigo que Don Hugo trajera de Espinar, está la fruta del valle, están todos, la madre y el padre, Juan de Matta con su silencio habitual, está doña Faustina, sirviendo al patrón; una ausencia fina se siente esta mañana, de pronto Arturo el capataz de Don Santos, entra agitado, en la desesperación que trae, dice - papá Santos, he visto a la niñacha María, escapando con ese Victurcha, se van lejos-, el padre toma la carabina, y con dos tiros al aire, su sentencia afirma.

María deja llevar con el viento sus lágrimas, como un par de besos lanzados para aquellas manos. Muy pronto se casa, Compone y su encanto son testigos de aquella unión, en su humilde casa festejaron y se sintió más libre que nunca, hicieron el Wasichakuy, cantaron, lloraron, y todo se fundió en un abrazo inmenso que brilló hasta el sol.

Aquella tarde, la mirada de don Santos, no tenía dirección, le había quitado una parte de sí, pero con todo el dolor, desheredó a su más preciada flor.

Víctor y María, sintieron la pobreza, el hambre, el amargo en la boca cuando falta el pan pero entre aquel enjambre siempre existió el amor. La abuela materna de María, Doña Irene, frecuentemente la ayudaba cuando a los niños mandaba a la Escuela, es largo el camino y la helada agrieta los pies descalzos, pero eso no importa hay que estudiar. Los cinco hijos, cruzaban el río helado en madrugada, aquellos piecitos descalzos caminaban kilómetros sobre los pastos escarchados, hasta llegar a Zurite, con los cuadernitos, los lápices, el borrador y aquella esperanza, de ser mejor. Mientras que el nuevo hacendado, único heredero del difunto Don Santos, enviaba a una escuela en la ciudad a sus hijos, con los zapatos bien lustrados.

Pasaron los años, los niños se hicieron hombres, y entre riñas, desventuras y amores, con el consejo de su madre y sudor de su padre se hicieron fuertes, y fueron todos profesionales, con las amarguras del hambre, de la pobreza, hicieron de las desventajas fuerza, ahora ven de lejos a los hijos del hacendado que se llenaron de riqueza para hacer deleite de los más aprovechados, y mientras un buen Velasco ha pesado, perdieron todo lo que robaron. 